\title{
CONTESTING RELIGIOUS AUTHORITY IN GHANA Perspectives on the Literary Works of Aminu Bamba
}

\author{
Yunus DUMBE \\ ydumbe.cass@knust.edu.gh \\ Victor Selorme GEDZI \\ KNUST, Kumasi, Ghana \\ vsgedzi.cass@knust.edu.gh \\ Osman Issah SEEKEY \\ KNUST, Kumasi, Ghana \\ osmanseekey@yahoo.com
}

Kwame Nkrumah University of Science and Technology (KNUST), Kumasi, Ghana

This paper examines the literary works of Aminu Bamba as a perspective of his contributions to Islamic reform and counter to religious unorthodoxy in intra-Tijaniyya power politics in Ghana. It pays particular attention to his interpretations of issues that pertain to theology, jurisprudence, and conflict resolution, among others. Analysing Bamba's reform ideas illustrates their uniqueness for emphasising intra-Tijaniyya discourse which considerably departs from the Sufi-Salafi polemic that largely characterises the debate on Islamic reform in Ghana. The article argues that Bamba's scholarly writings and proselytization focus, which hinge on shari'a values, have blurred religious boundaries thus offering new insight on intra-Muslim reform initiative.

KEYWORDS: Islamic reform, literary production, 'ulama', Fayda Tijaniyya, Salafi, theology, jurisprudence

\section{INTRODUCTION}

Islamic reform has been a vital tool of Islamic revival in Muslims' imagination after the demise of Muhammad. It provides the conduit through which religious values and authority are contested. The 'ulama' hold a unique position in the Islamic reform tradition by reinvigorating the religious sphere with their understanding of Islam and demonstrating 
unwavering concerns over how Muslim societies are deviating from the core values of religious principles.

This article offers a case study of the role of Aminu Bamba in promoting Islamic reform in Ghana through his literary works and proselytising activities. Aminu Bamba is a contemporary Muslim reformer within the Tijaniyya scholarly tradition and is respected across religious divides in Ghana. Bamba is not only a religious leader but a prolific writer who has contributed significantly on diverse issues on Islamic reform, including jurisprudence, theology, and inheritance. His activities challenge the dominant Tijani Islamic traditions in Ghana though such activities have been underexplored.

Analysing the reform ideas of Bamba is particularly illuminating. This is because he became relevant in the Tijaniyya movement at a time when the activities of some of the religious elite generated controversy and polarized the movement on account of tensions regarding some Islamic teachings. In specific terms, the Tijaniyya revival in the late 1950s through the Jama'at Faydat al-Tijaniyya (the Tijaniyya Community of Divine Grace), propagated by Ibrahim Nyass from Senegal, crystalizes a significant moment in Muslims power politics in West Africa and Ghana in particular. The revival reinvigorated the practice of tarbiyya and attracted the patronage from Muslims of diverse backgrounds who appropriated it for power and authority. Consequently, while the practice of tarbiyya generated considerable controversy as the masses embraced it and re-interpreted its relevance, leading 'ulama' in the Tijaniyya movement were either ambivalent or endorsed the populist understanding. Bamba demonstrated an outstanding position when he broke away from the chain of intra-Tijaniyya power politics to counter the sub-cultures propagated by the masses through propagation and scholarly writings.

By emphasizing the core values of Islamic principles at the expense of a sectarian agenda, Bamba offers a unique approach to proselytisation which considerably departs from the often polemical tone that has characterised Muslim reformers' activities and heightened inter-Muslim differences. The implication of this approach on inter-Muslim and intra-movement power politics cannot be glossed over because it blurs the religious boundaries of SufiSalafi dichotomies. It offers a common understanding of Islam which Muslims of diverse divides could come to terms with.

Scholarly works have been grappling with the meaning of Islamic reform and its scope in recent times. Aimed at inculcating stronger sense of spiritual dimensions and reconciling the understanding of Islam in light of modern changes and trends, ${ }^{1}$ Islamic reform has dominated the central place in the thinking of 'ulama' who have been contextualising the meaning of Islam in light of modern developments in their societies. Consequently, the religious activities of the 'ulama' in Islamic reform has led to the production of monumental scholarly works across diverse disciplines.

Taking Africa as an example, the leading Muslim elite have been engaged in one form of reform or the other. In his analysis of the reform project of some African Muslim leaders, Roman Loimeier argues that the pattern of Islamic reform is comprehensive and aims at transforming Muslim societies on social, religious, cultural, political or economic issues. ${ }^{2}$ The background of Al-Amin Bin Ali al-Mazrui (1875-1947) of the coastal city of Mombasa in Tanzania illustrates the daunting task that Muslim reformers go through to propose solutions to societal challenges. Though steeped in the traditional scholarship, he was critical of the 
fact that some 'ulama' see the religious teachings of Islam as amounting to retrogression and constituting an obstacle to development. To overcome this challenge, al-Mazrui refocused his reform project to instil confidence in religious practices in the youths while appreciating the relevance of Western technology and the consequence of the ever-secularised reform the Tanzanian society was undergoing at the peak of British colonial rule. ${ }^{3}$ This underscores the resilience of Islamic reform which aims at reflecting on the implications of new developments on religious values.

Aminu Bamba represents a unique figure in the Islamic reform tradition in a Muslim minority country like Ghana in recent times. However, his inspiration in reform is built on the activities of previous Muslim reformers whose literary works attracted academic interest. Al-Hajj 'Umar ibn Abu Bakr ibn 'Uthman ibn 'Ali al-Kabbawi al-Kanawi (c. 1858-1934) can be regarded as the father of Islamic reform in Ghana.

Krake's literary works paid less interest to traditional Islamic sciences but devoted much talent to works on history, commentaries on social issues in both Arabic and Hausa. ${ }^{4}$ More specifically, his reform ideas were centred on issues affecting his time such as the impact of colonialism on the Gold Coast and the Christian missionary activities as well as advocating Muslim unity in the midst of colonial rule. ${ }^{5}$ Krake demonstrated a strong dislike for British colonialism on the Gold Coast by describing it as an affliction like the rising sun which had been covered with dust. ${ }^{6}$ Krake left an indelible legacy when his disciples and the generation of their disciples dispersed in various parts of Gold Coast and modern Ghana to propagate his reform ideas.

While Umar Krake's reform project was neutral to sectarian labelling, the background of the postcolonial Muslim reform movements was more divisive on inter-Muslim issues. Ousman Kobo (2012) analyses the pattern of Islamic reform undertaken by young graduates from Saudi Arabia who were supported by Western-educated intelligentsia in Ghana, through the Islamic Research and Reformation Centre (IRRC) founded in 1969. The gist of Kobo's analysis was that while the IRRC's reform agenda originated from the intersection of ideas of modernity in three strands - the West African and Middle Eastern traditions of reform and influenced by Western secular education on Muslim societies - it polarized inter-Muslim relations in Ghana. He succinctly argues that Wahhabi reformers not only appropriated Western concepts for struggles against colonial policies that eroded Muslim influence but targeted the Tijaniyya 'ulama' with labels that portrayed them as people who propagated superstitious beliefs. ${ }^{7}$ Similarly, when discussing the Wahhabi reform movement spearheaded by Afa Yusuf Ajura, the Anbariyya Islamic movement in Tamale, Iddrisu Abdulai argues that while it did not benefit from external stimuli but fed on pre-existing Muslim power politics, it heightened inter- and intra-Muslim tensions in Dagbon. The movement gained considerable influence when it preached against 'superstitious beliefs' and costly social functions such as marriage, funeral, and naming ceremonies which imposed financial hardships on families. ${ }^{8}$ These early postcolonial Muslim reform movements share much in common in terms of their anti-Sufism and created much tension over inter-Muslim differences and conflicts in Ghana.

As this article largely depends on the unpublished literary works of Aminu Bamba, it was inspired by previous scholarly works which advocate an increased dependence on local manuscripts to construct Islamic discourse in modern Ghana in particular and West 
Africa in general. Wilks argues that tentative observations on the growth of the tradition of Islamic learning in the region now forming the modern state of Ghana, and occasioned by recent and rapid increase in the number of Arabic works known to scholars from that area, require critical study. ${ }^{9}$ Stewart and Weiss also argue that the importance of Arabic and Arabic-script, personal correspondence, commercial records, and legal records as well as religious developments which can be obtained through grey literature (both pamphlets and booklets published by the local religious elite) are relevant resources for contemporary researchers to construct the social and economic history of African Muslims. ${ }^{10}$

In spite of the fact that Bamba has written extensively on varied subjects on matters of national and religious interest, including astronomy, poetry, Islamic theology, and inheritance, in both Hausa and Arabic, such works have not attracted significant scholarly interest. The only works of Aminu Bamba which have been analysed were his poems in Arabic, which have been studied at the university level. ${ }^{11}$ The analyses to be presented are based on selected works of Bamba which are a combination of his thought in jurisprudence, theology and inheritance. These include The Right Time for Prayer, The Accepted Prayer is to Face Qibla, and Stoning in Islam, which focus on theology and jurisprudence. On the other hand, Fath al-Mannan (The Opening of the Bestower of Favour) which sheds light on his views on inheritance shall also analysed. Therefore, the primary source for this work are the writings of Bamba, but supported by field interviews to further clarify issues. Aminu Bamba can be classified as a religious thinker, whose influence and impact on the Muslim community must be evaluated as a critical part of religious discourse on what it is to be a practicing Muslim.

The analyses of the reform ideas of Aminu Bamba in this article are structured in four parts. As this study largely revolves around religious authority, the first part analyses empirical studies on how religious authority is legitimated. The second part analyses the religious milieu in which Bamba's ideas emerged. The transformation of the Tijaniyya movement in Islamic reform in modern Ghana has attracted activists who proposed diverse reform ideas that generated controversy. This is followed by a discussion of Bamba's background and the transformation of his scholarly leanings in the Tijaniyya movement. The fourth part analyses his reform ideas on theology, jurisprudence, and adjudication of inheritance issues, among others. The last section presents the conclusion of this study. Bamba's approach to Islamic reform in Ghana suggests that intra-Islamic reform discourse can significantly play a role to blur the religious boundaries which most often characterize inter-Muslim reform in polemical dimension and heighten tensions.

\section{RELIGIOUS AUTHORITY AND THE QUESTION OF LEGITIMACY}

Among the contemporary Muslim elite, the 'ulama' are thought to be at the receiving end of the consequences of modernity. Scholarly analyses have argued that - to paraphrase Zaman - the authority of the 'ulama' has been rendered redundant on a popular level in view of unrelenting technological transformations in modern times. ${ }^{12}$ On a surface level, this would seem to indicate that the 'ulama' are losing grip of their authority in the midst of emerging challenges. However, this perception underrates the resilient background of the 'ulama' and 
necessitates rethinking. Accordingly, Zaman aptly sums up the significance of the 'ulama' in the wake of modern challenges, arguing that they have demonstrated their capacity to adapt their discourses to changing societies. ${ }^{13}$ While significant factors are transforming Muslim identities in diverse ways - including global political reconfigurations with modern institutions, the emergence of modern intelligentsia in the Muslim world, and technological transformations - the authority of the 'ulama' has not been undermined significantly. Interestingly, the 'ulama' have navigated their roles in Islamic reform by articulating their discourses in the midst of these complex challenges. Taking Ghana as a good illustration of a Muslim-minority country, the 'ulama' have occupied a conspicuous position in shaping the debate on Muslim identities in inter-Muslim politics and in the broader inter-religious discourses.

The case study to be presented on Aminu Bamba illustrates the significance of religious authority in stimulating debates on Islamic orthodoxy in Ghana. This is, however, not overlooking the fact that religious authority is a complex subject that defies a simple understanding. Deriving its basis from the popular saying in Islam and attributed to Muhammad that 'the 'ulama' are the heirs to the prophets', religious authority in Islam has become a subject of contestation among Muslim elites of diverse ideological backgrounds. 'Ulama $\bar{a}$ ' is an Arabic word from 'ilm, meaning 'knowledge' (plural, 'ulama $\bar{a}$ ). It denotes those who are knowledgeable in the religious sciences. They exude moral authority among Muslims by virtue of their mastery and interpretation of Islamic scriptures, the Qur'an and hadith.

Quite revealing, the position occupied by 'ulama' in West Africa is not different from that in Ghana, thus enabling us to assess the relentless roles that they play in re-defining the socio-moral values of Muslim societies. Brenner has elaborated the various contours that this authority manifested in West Africa, including descent-based authority, the development of Sufi-based leadership, and the founding of Muslim political authority among others. ${ }^{14}$ This demonstrates that religious authority in Islam can be acquired or inherited, although depending on the masses' perception of the scholarly pedigree of the 'ulama' and its adherence to religious ethos. This exceptional privilege of the 'ulama' defines them - to borrow Mouline's expression - as a cultural, missionary, legal, and theological repository of Islam. ${ }^{15}$ In the perspective of Eickelman et al., the 'ulama' wield considerable power because they appear to embody cherished values and represent symbolic reference points of society. ${ }^{16}$

Scholarly works in recent times have been grappling with the foundation upon which the authority of the 'ulama' revolves. In this scholarship, political authority is distinguished from religious authority, since the former depends on coercion while the latter derives its basis from the willingness of followers to submit to the views of the religious elite ${ }^{17}$ Central to the authority of the 'ulama' is the question of the legitimacy of the discourse they stimulate. ${ }^{18}$ However, what constitutes legitimate religious authority in Islamic discourse is sometimes elusive, largely due to the contestation of the religious sphere by ideological movements in the Muslim world. This demonstrates the fact that religious authority is both an enduring and elastic concept, thus making it difficult for the Muslim elite to clarify the appropriate boundaries of Islamic orthodoxy. While Muslims of diverse backgrounds identify the sharica as the defining law of Islam, they do not hold a common understanding about its nature and scope. This raises a fundamental question about the legitimacy of religious authority which can be subjective and fluid, thus making it difficult to agree on its precise scope. 
Religious discourses were stimulated in line with the ideological agenda of one particular movement or the other. This further permeates the background of 'ulama' who belong to one particular movement or the other. The 'ulama' who belong to Islamic movements stimulate religious discourse in line with the ideology of the group in order to attract mass followers. Consequently, in addition to exuding authority on the masses, it enables them to transform their backgrounds into natural positions of leadership wherein they impose obligations on them. ${ }^{19}$

The fluidity of religious authority in Islam became apparent after the collapse of the reign of the third caliph of Islam, 'Uthman ibn 'Affan. This produced a schism leading to the development of religio-political groups in Islam. Since then, the Muslim sphere has been subjected to contestation of authority by diverse interest groups, and Muslims have not come to terms with what constitutes the framework of the legitimacy of religious authority in Islam. Brenner's insightful view that the legitimacy of the authority of 'ulama' may also depend on local social and political factors illustrates the complex issues at stake. ${ }^{20}$

Sub-Saharan Africa offers an example of how the religious sphere was a subject of contestation by diverse ideological groups on questions of religious authority in inter and intra-Muslim power politics. As highlighted earlier, religious authority has been exercised in inter and intra-Muslim power politics on questions of Islamic orthodoxy.

Loimeier argues that religious debate by the 'ulama' is not merely limited to dogmatic quarrels but involves multitude of interests both local and foreign. He illustrates how the religious differences between Abubakar Gumi and the Sufi movements in northern Nigeria were interlinked with trader-scholar networks for greater clienteles. ${ }^{21}$ Similarly, Kane elaborates on how business elites were connected with the leadership of the Yan Izala and $\mathrm{Da}^{\mathrm{c}}$ wa movements to secure access to business opportunities with Saudi Arabian business partners. ${ }^{22}$ Again, religious debates were relevant for 'ulama' to win the credibility of the masses and to establish political networks in inter and intra-movements' power politics. This illustrates the significance of religion as a form of social capital which actors accumulate to advance their proselytising agenda.

Taking Abubakar Gumi (1922-1992), the founder of the Yan Izala movement in Nigeria, as an example, he depended on the legacy of Uthman Dan Fodio to bolster his religious authority. Having translated most of Dan Fodio's scholarly works into Hausa, Gumi gained a reputation as an Islamic reformer (mujaddid). Consequently, he wrote books of a polemical nature such as Musulunchi da abinda ke rushi shi (Islam and the Things which Lead to its Corruption) to attack his religious opponents. He labelled his opponents in the Tijaniyya movement as 'ulama' al-sü' (evil scholars) and malluman bid'a (heretical 'ulama'), while the ruling elites who rebelled against his preaching were labelled as backward chiefs. ${ }^{23}$

In spite of the fact that religious authority may derive its vitality from the legitimacy of the discourse, it can sometimes contradict this perspective. The Tijaniyya litany of Salat al-Fatih, which can be found in the book fawahir al-Ma'ani, authored by Ali Kharazim, illustrates that the legitimacy of religious authority can be fluid. In this book, it is said that the Holy Prophet advised Ahmad Tijani (the founder of the Tijaniyya) that reciting Salat al-Fatih is equivalent to six recitations of the Qur'an. In hindsight, the average non-Tijaniyya Muslim may view this as antithetical to Islamic shari'a which may cast aspersions on the Tijaniyya adherents' patronage of it. Consequently, the attempts made by reformist elements within 
the Tijaniyya like Ibrahim Salih Husayni to correct this view have resulted in their being labelled by the movement's sympathisers in polemical terms as Wahhabis. ${ }^{24}$

Religious authorities are not only authorities based on what they propagate on pulpits. Some of the leading religious elite in Africa wield authority through literary production. Abubakar Gumi of northern Nigeria has published extensively on matters of religious beliefs and practices, just as Abdallah Salih al-Farsy (1912-1982), a disciple of Ali al-Mazrui, stimulated Islamic reform through literary production in East Africa. ${ }^{25}$ While previous Muslim elites in Africa stimulated Islamic reform by targeting the religious beliefs and practices of other groups in inter-religious reform polemics, Bamba situated his reform agenda in the intra-Tijaniyya movement which he belongs to, as analysed below.

\section{THE TRANSFORMATION OF THE TIJANIYYA IN ISLAMIC REFORM IN MODERN GHANA}

Ghana is a secular state but an overwhelmingly religious country. Moreover, Muslims represent a minority religious group in Ghana in an overwhelmingly Christian country. The 2010 national census put the population of Muslims at $18 \%$ while Christians represent 71\%. In spite of being a minority, Muslims exert considerable influence in national politics on account of a political convention whereby a Muslim is nominated as the Vice President by the major political parties. Significantly, Muslim populations are concentrated in the north while segregated settlements are scattered in southern communities called the Zongos. Consequently, the spatial distribution of Muslim populations in Ghana has been translated into political capital for national representation. Presently, Muslims enjoy two major national holidays in Ghana on the occasions of 'Eid al-Fitr (celebrated after the fasting of the month of Ramadan) and 'Eid al-Adha (the festival of sacrifice in commemoration of Abraham's sacrifice of Isma il). More importantly, the arena of Islamic reform represents a unique sphere where Muslim elites shape the debate on Islamic orthodoxy and religious authority is contested in Ghana.

While the context of this article revolves around Islamic reform, it is important to outline two interrelated processes shaping the Islamic sphere in Ghana, namely: Islamisation and revival. Islamisation, which is about the expansion and the spread of the religion, was a product of the trading activities of the Mande people (Wangara) in the Gold Coast. This was further sustained by migration as well as colonial officials recruiting Muslims from the neighbouring West African countries as the core of their security. ${ }^{26}$ The Islamic sphere in modern Ghana can be categorized into the indigenous Muslim population in the north and descendants of migrant Muslims in the south, though the legal regime recognizes the latter as Ghanaian citizens. Some indigenous Ghanaians in the south, especially the Gas, Asantes, and Fantis, were among the latter converts to the Islamic religion. ${ }^{27}$ The revival strengthened the faith among Muslims through scholarly works and pilgrimage, among other things. The Hausa Muslims from northern Nigeria played the revivalist role and, consequently, their language has become the lingua franca of Muslim communities. In terms of the Islamic movement, the Qadiriyya pioneered the Islamisation process, while the Tijaniyya derives its impetus from the activities of revivalists. 
The Qadiriyya and Tijaniyya strands of Islam derive their origin from Sufism, which is Islamic mysticism and involves meditation and esoteric beliefs. While the Qadiriyya pioneered the Islamisation spirit, it has, however, become extinct on account of the rigorous nature of its thought, its elitism for 'ulama', and its lack of social relevance both for the masses and transnational reformers. ${ }^{28}$

Deriving its name from the founder, Ahmed al-Tijani (1737-1815), the Tijaniyya movement has been transformed as a dominant Muslim movement in West Africa on account of several factors. The outstanding role it plays in Muslim social life for claiming to be spiritually superior over all other Muslim mystical movements comes to mind. This movement further benefited from the exceptional role of some Muslim elites, such as Muhammad Hafiz of the Idaw Ali tribe of Mauritania and Hajj Umar Tall of Masina. They appropriated their proximity of initiation as well as their background of the Torodbe Fulbe caste religious class to claim descent from the prophet Muhammad. ${ }^{29}$ In particular, the religious activities of the descendants of Umar Tall played significant roles in the growth of this movement in modern Ghana. This was after the fall of Segu in the Masina Empire which necessitated their eastward migration to the Gold Coast. ${ }^{30}$ Again, having embraced this movement, the Hausa people and local 'ulama' popularized its dominance.

The revival of the Tijaniyya movement in modern Ghana can be traced to the activities of two Muslim elites in the early and mid-twentieth century. Umar Krake (1850-1934), a Hausa from Kano, who was regarded as the supreme leader of Muslims in the Gold Coast, first pioneered the Tijaniyya revival. He performed pilgrimage to Mecca in 1913 and was initiated into the Tijaniyya movement by Alfa Hashim, the nephew of Umar Tall. This changed his religious allegiance from the Qadiriyya background. ${ }^{31}$ Umar Futi, a grandson of Umar Tall, also initiated leading 'ulama' including Imam Abass of Accra into the Tijaniyya movement. The initiation of Krake represented a catalyst in the transformation of the Tijaniyya movement in modern Ghana. He embarked on propagation to communities in addition to his teachings to disseminate the movement's thought. His outstanding contribution in the proselytization of Tijaniyya was when he initiated into the movement most of his students who dispersed to different communities to propagate the order. ${ }^{32}$

Since the 1950s, the Tijaniyya have also attracted a new revivalist, Ibrahim Nyass (19001975) from Senegal. His revival of the Tijaniyya shaped the contemporary outlook of the movement in Ghana. He founded the Jama ${ }^{c}$ at Fayda Tijaniyya (the Tijaniyya Community of Divine Grace) as the catalyst of his Tijaniyya revivalism in West Africa. This projected his image as șạhib fayḍ ("bringer of the Fayda") which carries a populist expansion of the Tijaniyya. $^{33}$

The Fayda Tijaniyya of Nyass was appealing to the masses because it popularised and liberalized the practice of tarbiyya which is a mystical way of experiencing God. While tarbiyya was practiced previously through meditation, fasting, and seclusion among the learned elite, Nyass encouraged the masses to embrace its practice without recourse to these rigorous conditions. ${ }^{34} \mathrm{He}$ embarked on proselytization of this new movement in West Africa and visited a number of the West African countries including Ghana. He visited Ghana three times beginning from 1952. In 1965, he came to Ghana as the guest of President Kwame Nkrumah of Ghana who identified Nyass as his spiritual father. ${ }^{35}$ Some of the disciples of Nyass in the 1950s included Babal Waiz, Muhammad Haruna, and Usmanu Nuhu Sharubutu 
(National Chief Imam), who among others became the leading 'ulama' to propagate the dominance of the Fayda Tijaniyya movement.

One of the leading Ghanaian 'ulama' who played a role in the propagation of the Fayda Tijaniyya was Abdallah Ahmed Maikano Jello (1928-2005). He emerged at a time when the Fayda Tijaniyya popularization of the tarbiyya had degenerated into controversy. Ordinary Muslims who practiced the tarbiyya translated its relevance to imply 'seeing God'. Maikano vehemently defended the tarbiyya practice and attracted considerable admiration and respect among the sympathisers of the Tijaniyya. ${ }^{36}$

His legacy in the defence of the Fayda Tijaniyya was not without controversy - a development that informs Aminu Bamba's counter-reform ideas. For instance, Maikano was perceived to have endorsed the masses' and populists' understanding of the tarbiyya as 'seeing God'. He further tolerated the mingling of both sexes and drumming and dancing during mawlüd (the celebration of the birthday of the Prophet of Islam). Maikano might not have been a bad religious figure, but rather his avowed agenda was to attract the masses. The perceived imbalance associated with his proselytization and views was his lack of sensitivity to Islamic sharica issues. Maikano was perceived to have argued that he had the powers to manipulate the spirit to the advantage of human interest. Eventually, Maikano attracted the ire of leading 'ulama' when he was perceived to have married more than four wives, a limit set by the Islamic sharica. In terms of influence, Maikano is more popular with the masses than other Tijaniyya leaders in Ghana. His religious activities have led to the emergence of a religious sub-group called the Jello Tijaniyya and referred to in the Hausa language as Yan fello (followers of Jello). The controversies and the disintegration in the Tijaniyya movement were capitalised upon by the Salafis to deride the perceived drifting away of the former from Islamic teachings. ${ }^{37}$

When the Salafis' censure of the Fayda Tijaniyya movement was at its peak in the 1980s and 1990s, it was Aminu Bamba, another leading Tijaniyya, who refuted the religious ideas espoused by Maikano through his writings. His al-Qawl al-Haqq: al-Fasil Bayn al-Haqq wa al-Batil (The Truth that Separates Right from Wrong) is a catalogue of his theological views that sought to preserve the Tijaniyya orthodoxy.

\section{SHAPING THE REFORM IDEAS OF AMINU BAMBA}

Aminu Bamba was born to Yakubu Yusuf and Adama Saeed in the 1950 os in Accra New Town of the Greater Region of modern Ghana. He later migrated to Ejura in the Ashanti region to stay with Alhaji Ahmed, where he had his basic secular education at Ejura T. I. Ahmadiyya School. After studying in Ejura for a while, he moved to Tamale in the Northern Region to further his studies and thereafter to Kano in northern Nigeria. His migration to Kano in 1976 was a catalyst in the transformation of his life from a disciple to an Islamic theologian, jurist, and reformer. In Nigeria, he studied under Mallam Zakaria and other prominent 'ulama', specializing in the area of Maliki jurisprudence and Islamic inheritance.

He returned to Ghana in 1983 to undertake the propagation of his reform ideas. For the first ten years of Bamba's stay in Ghana, he travelled across the length and breadth of the country to propagate Islam. This has won him admiration as a respected Islamic scholar. 
Kamaldeen Ahmed (d. 2018), the Deputy National Chief Imam, intimated that he became associated with Bamba because of his straightforwardness on Islamic theological issues. ${ }^{38}$ Kamaldeen's appraisal of Bamba is not surprising because they both share a common sentiment against tarbiyya populism. Bamba later settled in Ejura, where his contribution to the community is evident in the founding of Ihya al-Din - an Islamic school he built for teaching secular and Islamic studies. ${ }^{39}$ This section largely focuses on his contributions to literary production which have not received attention in recent time.

This is not to say that Bamba's reform ideas are restricted to literary production. According to Mallam Rufai, a former student of Bamba, Bamba's educational reforms revived Islamic education in the Ejura community which appeared to have collapsed before his arrival. His initiative supports Loimeier's argument that most Muslim reform movements are movements of education. ${ }^{40}$ Thus, Muslim reform movements have, in his view, stressed the paramount importance of not only Islamic religious education, but also modern (Western) education, and again, not only education for men but also for women.

Religiously and socially, Bamba preached and lectured in mosques and public gatherings. This was intended to shape the behaviour of the youth and the elderly in the community, whom he perceived to have been corrupted. He also popularized the hijab (headscarf for Muslim women) and preached against the mingling of both sexes in public gatherings. In addition to this, he cultivated an 'anti-bid'a' (anti-religious innovation) type of reform which censures religious heterodoxy in the Tijaniyya movement.

Bamba's reform had as its focus a censure of the local religious and traditional practices which had crept into the Sufi orientation in Ghana. In fact, aspects of Bamba's reform ideas were not in the interest of many Tijaniyya followers. His censure of the Tijaniyya sometimes attracts the subtle pejorative label from some hardline Tijaniyya followers that Bamba is a disguised Salafi. Bamba's focus in promoting Islamic orthodoxy may sometimes necessitate him to discredit his peers in public. He was known to have challenged Salis Shaban when the latter argued that the practice of tarbiyya as popularised by the masses must be upheld during the mawlüd celebration in Kumasi. Bamba, in his usual fashion, discounted this view arguing that the Tijaniyya values constitute an integral part of the shari'a and not vice versa. ${ }^{41}$

Similarly, some Salafi 'ulama' see him as a refined Tijaniyya who propagates authentic religious values. Hassan Shuaib (d. 2017), a Salafi graduate from Medina University in Saudi Arabia, had initially perceived that Bamba was brought from Nigeria purposely to counter his Salafi agenda in Ejura central mosque. However, the balanced position Bamba adopted on religious matters won him admiration and respect in the community. Though steeped in the Tijaniyya religious worldview, Bamba advocates that Muslims comply with strict sharica principles as enunciated in the Qur'an and hadith and avoid all forms of bid'a.

Bamba is also respected for his role as a Muslim jurist and a muftit ${ }^{42}$ who mediates on Muslim social issues. This formed an integral part of his reform program. As a mufti, he applies Islamic rulings to relevant Muslim social issues, events, and emerging trends. This prompted people across the country and beyond to identify him for legal interpretations on matters of Islamic inheritance and dispute resolution cases among others. As an authority on arbitration on family issues, Bamba's activities have endeared many people to him and attracted national attention. He has become a reference point of secular law courts on matters of inheritance from an Islamic perspective. Legal cases on matters of Muslim family law are 
referred to him for settlement. His legal decisions are most often endorsed by the law court as conclusive. In other scenarios, aggrieved parties who sought Bamba's private rulings but later disagreed with his decisions are referred to the secular law court. Interestingly, the law court most often ends up endorsing Bamba's previous ruling on the said case. In the field of literary production, ${ }^{43}$ he has to his credit several literary works including prose and poems written in both Arabic and Hausa. However, most of his works have not been published; some will be discussed below.

\section{The reform thought of Aminu Bamba}

The reform ideas of Aminu Bamba are broad though largely revolving around religious issues and specifically theological and jurisprudential perspectives. Bamba demonstrates considerable depth on religious issues, including jurisprudence, theology, and inheritance, which distinguishes him from other Muslim reformers such as Umar Krake. Unlike Bamba, the Krake reform project focuses on politics, Muslim unity, African history, the implications of European colonialism in Africa, and the Christian influence in the Gold Coast among others. ${ }^{44}$ The differences in reform thought between Krake and Bamba is not surprising, though they underline the fact that they are products of their time. Krake was a product of the colonial period which attracted his attention in his reformist thought whilst Bamba emerged in the postcolonial period when the Tijaniyya revival stimulated by the Fayda movement generated controversy, as the analysis highlights below.

Like Umar Krake, Aminu Bamba is a Tijaniyya in leaning. However, he confessed to us during an interview that he neither belongs to the Fayda Tijaniyya nor any other Islamic organization. He believes and practices the tarbiyya as enunciated in Sufism (Islamic mysticism) in general and he believes its principles do not conflict with the shari a.7 Because of Bamba's neutrality on the Islamic movement, his opponents in the Tijaniyya label him as munkir-faila for having in common some levels of theological views with the Salafis. The underlying differences between him and his opponents - mainly, adherents of the Maikano version of the Tijaniyya - always revolve around theological issues. Bamba takes strong exception to certain religious positions espoused by Maikano's sympathisers which he views as antithetical to Islamic sharica values. Bamba is critical of issues relating to drumming and dancing during religious ceremonies and the mingling of the opposite sexes as well as marrying more than four wives and certain religious pronouncements.

The main reference to Bamba's theological views in connection with the issues of disagreement with the Fayda Tijaniyya movement is his manuscript al-Qawl al-Haqq: al-Fasil Bayn al-Haqq wa al-Batil (The Truth that Separates Right from Wrong). The 78-page work is an unpublished manuscript which was written in Arabic in August 1997. This manuscript was written as a counter-response to the perceived un-Islamic and unusual practices and beliefs that emerged within the Tijaniyya brotherhood in the past decades in Ghana. In this manuscript, Bamba analyses, among other things, marrying more than four wives, the free mingling of opposite sexes in religious gatherings, drumming, and dancing, all of which were promoted by Maikano. Abdullah Maikano Jello had declared that he was better than the Prophet for having performed prayers and hajj more times than the Prophet. In fact, 
Bamba went to the extent of describing some of these beliefs and practices as amounting to disbelief and apostasy.

Bamba's theological reforms were met with strong opposition and mixed reactions from the Fayda Tijaniyya sympathisers. These included, but were not limited to, insults and assault, dismissal from the residence of Maikano's ardent supporter, and the deprivation of the opportunity to attend the annual hajj. Also, some of Bamba's family members severed times from him. This indicates the passion that people attached to their religious position which highlights the level of religious intolerance and extremism within the Fayda Tijaniyya fraternity. Bamba could not leave this bitter experience out, and he discusses it extensively in the manuscript.

After fourteen years of separation and serious debate, an attempt was made by the leading elders of the Tijaniyya to reconcile Bamba and Maikano, but to no avail. It was this context that prompted Bamba to write another manuscript to put forward the conditions necessary for reconciliation on matters of Islamic theology. He states in the introduction:

It appeared to me these days where reconciliation is the topic of the day across the country. It becomes necessary to write a book and explain my stance, school of thought and theological views before my death. ${ }^{45}$

Bamba states emphatically that reconciliation will never be achieved unless the two parties accept the shari'ah as the basis of law to govern their lives. Since this condition could not be met, Bamba has stayed apart from the Fayda Tijaniyya movement to this time. One can, however, argue that differences of opinion must not be the basis for hatred, enmity, and separation amongst the Muslim fraternity. This is because Islam encourages peaceful co-existence and reconciliation even with non-Muslims despite theological differences. Bamba could therefore have ignored this point in his religious pronouncement.

Bamba's theological views can also be gleaned from his other works like Complaint to Almighty Allah and Do you know Allah? His poem, 'Complaint to Almighty Allah' for instance is a 33-stanza poem that sought to promote reliance on Allah especially in times of difficulty and adversity. In August 2014, he composed this poem to console himself while he was battling a fever. ${ }^{46}$ In this poem, he also sought to explain his view on the concept of faith in Islam. This concept, which portrays God as Supreme, also refutes human divinity in the case of Jesus Christ, as is reflected in Christian teachings. This stance is built on the premise that human beings are relatively weak, hopeless, and incompetent and cannot benefit or harm others. The poem Do you know Allah? also demonstrates his views on the existence of God, His names, attributes and their interpretations, and seeing God in the hereafter, among others. ${ }^{47}$ This piece emphatically reveals his inclination to the Sunni school on matters of Islamic theology.

On Islamic jurisprudence, Bamba tried as much as possible to guide Muslims on prayer-related issues. Key among these perspectives include his views on prayer times and the direction for prayers. These two perspectives have been expressed in his books The Right Time for Prayer, and The Accepted Prayer is to Face Qibla. ${ }^{48}$ His views on prayer times and the direction for prayer were borne out of people's negligence towards prayer times. In solidifying his views, he used the traditional method, where he erected a strong straight metal 
rod in the ground and drew circles in one-foot intervals around the pole on cement. The pole measured up to seven feet above the level of the ground. Following this, he observed the course of the sun's movement and its relationship with the shadow from January to December. He noted that on 1 January, the sun reaches the meridian at exactly 12:11 pm and that the shadow at the mid-point (zill zawāl) is four feet and half an inch. He argued that a reduction in the shadow of the pole to its lowest point at the mid-point would necessitate a time period of about 1o to 15 minutes before it starts to increase towards the west.

Aminu Bamba stressed that such a phenomenon does not appeal to visual observation. On 1 January, the shadow increases 1 inch at exactly 12:26 pm and this, to him is, supposed to be the first time of the $z u h r$ prayer, contrary to $12: 11 \mathrm{pm}$, which was proposed by the astronomers who focused only on the position of the sun at the mid-point. The $z u h r$ prayer must not be offered right after the sun has reached the meridian but rather when its shadow starts to incline towards the west. This view varies depending on particular months and geographical locations. But the difference must be taken into consideration so that prayer time will not remain static.

However, in view of the geographical and climatic differences among the regions in Ghana, he proposed a timetable for Accra ${ }^{49}$ which was also suitable to be used throughout the country. In doing so, he considered the geographical and climatic differences between the southern and the northern parts of the country, suggesting that prayer times in the north must be adjusted by ten minutes. He further cautioned that ten minutes have been deliberately taken out from the dawn prayer (fajr) as a margin of safety for the fasting person, especially for those in Kumasi, Brong Ahafo, and the three Northern Regions, who could therefore add ten minutes to their fajr time. This arithmetic invariably suggests that with the exception of the five Northern Regions, Ashanti, and Brong Ahafo, the timetable could be used anywhere in Ghana without further adjustment.

Nonetheless, Aminu Bamba's position needs a critical assessment because of the geographical and climatic differences among the sixteen regions of Ghana. The prayer timetable issued by the Saudi Embassy, however, stipulates these differences. It could also be argued that he had considered all of these possibilities and this information before suggesting the addition of ten minutes as a maximum within which all other regions except Accra must fall. The implication is that it would be better for a person to pray after than before the said time, putting the Ashanti, Brong Ahafo, and other regions into perspective.

In part, Bamba's methodology used to construct the prayer timetable has been further corroborated with recent technological developments. In particular, digital technology is being employed to shed new insight on how to determine the timetable for Muslim daily prayers. It highlights the fact that fajr (the dawn prayer) ends with the start of sunrise, whereas $z u h r$ (noon) is considered at a slight margin from midday time. ${ }^{50}$

While aspects of Bamba's postulations overlap with modern technological innovations, it lacks comprehensive application for all the five daily prayers. That is to say, the erected pole can only be used to determine times for the $z u h r$ and 'aṣr prayers (noon and afternoon prayers) and may not be applicable to the dawn prayer ( $f a j r)$ and the two evening prayers (magrib and $i s h \bar{a}^{\prime}$ ).

Besides, its application to the entire country appears quite ambiguous. Bamba was therefore compelled to accept and use some works of astronomers - like the prayer timetables 
distributed by the Saudi Embassy in Ghana - to determine times for the maghrib and $i s h \bar{a}^{\text {’ }}$ prayers. But in this case, he often adds some minutes as a margin of safety or error. He, however, made an exception in the case of the fajr prayer. According to him, since daylight is something that can be seen, he could rely on his personal judgment in the case of the fajr (dawn) prayer. He concluded that the time period between the appearance of daylight and sunrise must be at least one hour. Thus, the sun often rises one hour after the appearance of daylight. Therefore, if one cannot determine daylight, one can perform the fajr prayer one hour before sunrise. The emphasis on correct prayer timetables in recent times is a result of the impact of Islamic revivalists. Rock-Singer argues that Muslim reformers have stridently succeeded in projecting the religious calendar to represent a 'sacred' or 'authentic' time in order to cultivate pious subjects and shift the attention from modern secular ethics to the Islamic theological corpus. ${ }^{51}$

Furthermore, Bamba's The Accepted Prayer is to Face the Qibla seeks to clarify the hadith that says 'whatever is between the east and the west is qibla'. Qibla simply means facing eastward in Ghana towards the direction of the Ka ba in Mecca, Saudi Arabia. This book sought to educate people on how to determine the proper direction to face for prayers. According to him, this direction is specified for the people of Medina and those who are in its direction like Syria, Iraq, Turkey, Iran, and Jordan. However, the qibla for the people of Ghana and some of the West African countries such as Nigeria, Benin, and Togo is between east and north. This is because the Ka'ba, which is the direction of the qibla and situated in Mecca, is found between north-eastern parts of these West African countries. Bamba's outstanding contribution in this work is also manifested in his ability to suggest some natural ways of determining the qibla. They include:

1. The sun (sunrise)

According to him, on the following dates, when you face the sun, you will be facing the qibla because the sun will be directly above the Ka'bah:

a. From 1 to 13 May

b. From 1 to 13 August.

2. The shadow

The shadow of an object coincides with the qibla on the following dates and times:

a. From 1 to 4 October from 3:00 pm to 3:15 pm

b. From 5 to 9 October from 3:05 pm to 3:20 pm

c. From 10 to 14 October from 3:10 pm to 3:25 pm

d. From 15 to 16 October from 3:20 pm to $3: 30 \mathrm{pm}$

e. On 17 October from 3:25 pm to 3:35 pm

f. From 18 to 20 October from 3:30 pm to $3: 45 \mathrm{pm}$

3. Sunset

The sun sets at the backward direction of the qibla from 1 December to 1o January. 
4. The bright star in the west.

This star coincides with the qibla backwardly from 1 September till 13 September.

5. The brightening star in the east prior to the $i s h \bar{a}^{3}$ prayer.

According to the author, there are two bright stars in this direction; one on the right and the other on the left. The one on the left is brighter and beneath the one on the right. The brighter star on the left coincides with the qibla from 1 to 25 February from 7:00 pm to 8:00 pm.

6. The bright star which appears in the far east during the fajr prayer (Zuhra).

The author argues that this star does not coincide with the qibla in Ghana but rather tilts a bit towards the left. This often happens in August when a person is required to shift towards the right to coincide with the qibla. Nonetheless, this star meets the qibla from 10 September till the end of September. It only shifts away from the qibla from 1 October to November.

Stoning, as reflected in the Islamic sharicah, is another controversial issue that is addressed in Aminu Bamba's thoughts on Islamic jurisprudence. On this subject, he argues that stoning is an integral part of Islamic sharica that must be applied to the adulterer and adulteress when found guilty regardless of the circumstances. A study of the history and evolution of the Islamic shari'a suggests that its application is circumstantial. This means that the responsible institutions for the execution of penalties - for instance, the head of the Islamic states - must understand and take into consideration the circumstances within which a particular crime was committed before issuing a verdict.

However, possibilities may arise that lead to the suspension of the penalty taken into consideration the circumstances at present as were done by 'Umar ibn al-Khattab during the 'Year of Drought'. In that regard, Bamba does not appear to advocate stoning within the Ghanaian community, knowing that it strictly conflicts with the secular laws of the country. Nonetheless, it can be argued from the author's position that should the Ghanaian Muslims have their way to practice the sharica law, penal laws would be the responsibility of the state while Islamic family laws would be enforced.

On Islamic inheritance, Bamba's ideas are largely in line with medieval Islamic jurists' perspectives. It appears that Bamba might have succumbed to the maxim of medieval jurists that 'the gate of ijtihād is closed'. However, on the contrary, his position must be seen as reinforcing the Maliki school of thought which is the prevailing jurisprudential orientation of Muslims in West Africa. Evidence supporting this claim can be gleaned from some translated works from Arabic to the Hausa language which are summarized versions of his views. Additionally, some of his works involve massive reviews backed by his personal contributions and viewpoints.

Bamba considers his Fath al-Mannan (The Opening of the Bestower of Favour) ${ }^{52}$ his dearest written manual. This work reveals a unique disposition of Bamba's thought. The uniqueness of the work is evident in the Qur'anic exegeses and jurisprudential techniques he employs in analysing the verse on inheritance in Chapter 4 of the Qur'an. Bamba explained the verse with quotations from the Sunni collections of hadith, opinions of the Companions of the 
Prophet, and the scholars of tafsìr like Suyuti. After quoting Qur'an 4:7, Bamba explains it and further states the background of its revelation. According to him, Aws ibn Thabit al-Ansari died and left behind his wife and three daughters. Two of his male cousins, who were his inheritors, came and took all his possessions. Aws' wife came to the Prophet and told her story. The Prophet said, 'Return home until I see what Allah instructs.' Subsequent to this was the revelation of the aforementioned verse which simply indicates that both men and women inherit. ${ }^{53}$ With the aid of a diagram, Bamba vividly elaborates how the above case could be handled.

\begin{tabular}{|l|l|l|l|}
\hline Base no. & 24 & \multicolumn{2}{|l|}{} \\
\hline New base no. & 144 & 3 & 18 \\
\hline The wife of Aws & $1 / 8$ & & 32 \\
\hline Daughter 1 & & 16 & 32 \\
Daughter 2 & & 32 \\
Daughter 3 & $2 / 3$ & & 15 \\
\hline Cousin 1 & & 5 & 15 \\
Cousin 2 & residue & 5 & \\
\hline
\end{tabular}

\section{Analysis of the above diagram}

Aws died leaving behind a wife, three daughters, and two cousins. The share of the wife is $1 / 8$. The share of the three daughters together is $2 / 3$. The remainder goes to the two cousins. By multiplying the denominators of $1 / 8$ and $\frac{2}{3}$, one gets 24 as the base for distribution. Because the remainder will be 5 which cannot be shared evenly between the two cousins, the number of the daughter (3) was multiplied by the number of cousins (2) to arrive at 6 . The result (6) is further multiplied by the main base (24) to arrive at 144 as the new base. With the new base as 144, the property can be shared respectively without any complication. Eventually, the wife takes 18 . The three daughters take 32 each, and the two cousins take 15 each as the remainder.

\section{CONCLUSION}

This paper examined the reform ideas of Aminu Bamba through his literary works and proselytizing activities in Ghana. It paid particular attention to his interpretations of issues that pertain to Islamic theology, jurisprudence, inheritance, and conflict resolution. The study highlighted that Bamba demonstrated considerable depth in his reform ideas cutting across a wide range of issues from questions of religious unorthodoxy in intra-Tijaniyya power politics, the appropriate timetable for prayer, the formula for the distribution of inheritance, and the appropriate direction of the qibla. 
These ideas are not only novel but were articulated in different mediums which were hitherto not common. In the first place, the originality in the reform ideas of Bamba must be seen in the light of the fact that the Islamic revival was largely articulated by new religious elites from Middle Eastern centres of learning who accused the Tijaniyya elite of tolerating religious unorthodoxy and promoting sub-cultures. Consequently, this has emboldened the new elites as vanguards of Islamic orthodoxy who seek to return Islamic culture to its pristine background. Bamba's reform project challenged this perception by demonstrating through his religious ideas that the Tijaniyya movement has an equally inbuilt revivalist impetus. He reinvigorated Islamic reform in the Tijaniyya tradition, and it blurs the religious boundaries with other movements. This restored not only pride among the Tijaniyya but promoted a coherent theological worldview which matches the standard of their opponents.

This brings into focus the medium through which his reform ideas were articulated. The promotion of Islamic discourse through literary works was unique because it propelled the tradition of Islamic reform to a different dimension in Ghana. While this might sound like an elitist endeavour exclusively targeting the literate class of society, it preserves Islamic tradition and culture for posterity. The literature becomes a useful resource for young students to depend on during their mentorship to appreciate the pattern of Islamic reform of the previous generation. It is not surprising that his reform ideas are patronized by his disciples and admirers in their quest of higher knowledge. Abdul Mumin Harun, the regional Imam of Ashanti, and Abdul Wadud Haron, the za'im (leader) of the Tijaniyya movement in Ghana, further underscore the relevance of literary work arguing that it helps preserve the Islamic tradition and culture. ${ }^{54}$ More importantly, the Bamba reform project was given a boost as the Government of Ghana has incorporated Arabic studies in training colleges.

The relevance of Bamba's reform ideas on the enforcement of prayer timetables and the direction of qibla has awakened religious consciousness on performance of rituals at the appropriate time and manner. The significance of Aminu Bamba's religious thought must be seen from the fact that he has defied the scholarly tension between the Sufis and Salafis on most Islamic theological issues by reinvigorating the true spirit of Islamic shari'ah which Muslims of diverse divides may agree about. As a contemporary Muslim reformer, Aminu Bamba is a product of his time whose religious thought pays little regard to setting a sectarian agenda which polarised the Muslim sphere and caused the loss of life and property, and human displacement.

\section{NOTES}

1. Abu Khalil As'ad and Mahmoud Hadad, 'Revival and Renewal', The Oxford Encyclopaedia of the Islamic World (Oxford Islamic Studies online), accessed 10 December $2009<\mathrm{http}: / /$ www.oxfordislamicstudies.com/ article/opr/t236/eo682>.

2. Roman Loimeier, 'Patterns and Peculiarities of Islamic Reform in Africa', Journal of Religion in Africa 33, no. 3 (2003): $237-262$.

3. Randall L. Pouwels, 'Sh. al-Amin B. Ali Mazrui and Islamic Modernism in East Africa, 1875-1947', International fournal of Middle East Studies 13, no. 3 (1981): 329-345. 
4. John Hunwick, Arabic Literature of Africa: Volume 4: The Writings of Western Sudanic Africa (Leiden: Brill, 2003).

5. For more about Umar Krake, see Umar M. Abass, 'Alhaj Umar Ibn Abibakr Ibn Uthman Kreke Kete Krachie: A Ghanaian Muslim Poet' (MA dissertation, Department of Arabic Studies, American University in Cairo, 2002); Abdul Razak Iddriss, 'Alhaj Umar of Keta Krachie, a Muslim Leader, a Poet, and Social Commentator' (MPhil thesis, Department for the Study of Religions, University of Ghana, Legon, Accra, 1996); Holger Weiss, 'Muslim Scholars Living in Three Worlds: West African Muslims and the Imposition of the European Colonial Order', in Locating the Global: Spaces, Networks and Interactions from the Seventeenth to the Twentieth Century, ed. Holger Weiss (Berlin: de Gruyter, forthcoming (2020)).

6. Abdul Razak Iddriss, 'Alhaj Umar of Keta Krachie'.

7. Ousman Kobo, Unveiling Modernity in Twentieth-Century West African Islamic Reform (Brill: Leiden, 2012).

8. Iddrisu Abdulai Contesting Islam: Homegrown Wahhabism, Education and Muslim Identity in Northern Ghana, 1920-2005 (Proquest: Umi Publishing, 2011).

9. Ivor Wilks, 'The Growth of Islamic Learning in Ghana', Journal of the Historical Society of Nigeria 2, no. 4 (December 1963): 409 .

10. Charles Stewart, 'Towards an Agenda for Research on Islam in Twentieth-Century Africa', Institute of Muslim Minority fournal 7, no 1 (1986): 227; Holger Weiss, Between Accommodation and Revivalism: Muslims, the State and Society in Ghana from the Precolonial to the Postcolonial Era (Helsinki: Finnish Oriental Society, 2008). 11. See Abdallah Ishaq, 'Literary Analysis of Mohammed Amin Bamba's Poems' (MPhil thesis, University of Ghana, 2015); Abubakr Ismail, 'Literary Devices in the Poems of Aminu Bamba' (BA Dissertation, Islamic University of Niger, 2011).

12. Muhammad Q. Zaman, The Ulama in Contemporary Islam: Custodians of Change (New Jersey: Princeton University Press, 2002).

13. Muhammad Q. Zaman, 'The Ulama and Contestation on Religious Authority', in Islam and Modernity: Key Issues and Debates, ed. Muhammad. K. Masud, Armando Salvatore, and Martin van Bruinessen (Edinburgh: Edinburgh University Press, 2009).

14. Louis Brenner, Controlling Knowledge, Religion, Power and Schooling in a West African Muslim Society (London: Hurst \& Company, 200o).

15. Nabil Mouline, The Clerics of Islam: Religious Authority and Political Power in Saudi Arabia, trans. E. Rundell ([United States]: Yale, 2014).

16. D.F. Eickelman and James Piscatori, Muslim Politics (Princeton: Princeton University Press, 1996).

17. Gudrun Kramer and Sabine Schmidtke, 'Introduction: Religious Authority and Religious Authorities in Muslim Societies. A Critical Overview' in Speaking for Islam: Religious Authorities in Muslim Societies, ed. Gudrun Krämer and Sabine Schmidtke (Leiden and Boston: Brill, 2006): 1-14.

18. Louis Brenner, Controlling Knowledge: Religion, Power, and Schooling in a West African Muslim Society (Bloomington: Indiana University Press: 2001).

19. Gudrun Kramer and Sabine Schmidtke, 'Introduction: Religious Authority and Religious Authorities in Muslim Societies'.

20.Louis Brenner, Controlling Knowledge.

21. Roman Loimeier, Islamic Reform and Political Change in Nothern Nigeria (Evanston, Illinois: Northwestern University Press, 2011).

22. Ousman Kane, Muslim Modernity in Postcolonial Nigeria: A Study of the Society for the Removal of Innovation and Reinstatement of Tradition (Leiden: Brill, 2003).

23. Roman Loimeier, Islamic Reform and Political Change in Northern Nigeria. 
24. Rüdiger Seesemann, 'The Takfir Debate: Sources for the Study of a Contemporary Dispute Among African Sufis Part I: The Nigerian Arena', Sudanic Africa 9 (1998): 39-70.

25. Roman Loimeier, 'Patterns and Peculiarities of Islamic Reform in Africa', fournal of Religion in Africa, 33, no. 3 (2003): 237-262.

26. Yunus Dumbe, 'Islamic Revivalism in Contemporary Ghana', in Islamic Africa 9, no. 1 (2018): 113-117. For more on Islamisation, see David Owusu-Ansah, Islamic Talismanic Traditions in Nineteenth-Century Asante (Lewiston, NY and Lampeter: Edwin Mellen, 1991); David Owusu-Ansah, 'Islamization Reconsidered: Asante responses to Muslims in the Nineteenth Century', Journal of Asian and African Studies 21 (1987): 145-163.

27. David Skinner, 'Islamic Education and Mission Work: Ghana, and Gambia in the Post-Colonial Era' (paper presented at the African Social History Workshop, Stanford University, 1983).

28. Yunus Dumbe, 'Islamic Revivalism in Contemporary Ghana'.

29. Patrick Ryan, 'The Mystical Theology of Tijānī Sufism and Its Social Significance in West Africa', fournal of Religion in Africa 30, no. 2 (2000): 208-224.

30. Charles Stewart, 'The Tijaniyya in Ghana: a Historical Study' (MA dissertation, Institute of African Studies, University of Ghana, Legon, Accra, 1965).

31. Charles Stewart, 'The Tijaniyya in Ghana'.

32. Abdul Razak Iddriss, 'Alhaj Umar of Keta Krachie'. For the history of Muslim teachers whose students are historically known to have impacted the spread of Islamic theological thought, see Ivor Wilks, 'Al-Hajj Salim Suwari and the Suwarians: A Search for Sources', Transactions of the Historical Society of Ghana 13 (2011): 1-79.

33. Andrea Brigaglia, 'The Fayda Tijaniyya of Ibrahim Nyass: Genesis and Implications of Sufi Doctrine', Islam et sociétés au sud du Sahara 14-15 (2001): 41-56.

34. Rüdiger Seesemann, The Divine Flood: Ibrahim Niass and Roots of Twentieth Century Sufi Revival in West Africa (Oxford: Oxford University Press, 2011).

35. Abdul Razak Iddriss, 'Alhaj Umar of Keta Krachie'.

36. Yunus Dumbe, 'Islamic Revivalism in Contemporary Ghana'.

37. Yunus Dumbe, 'Salafi Praxis of Constructing Religious Identity in Africa: A Comparative Perspective of the Growth of the Movement in Accra and Cape Town', Islamic Africa 2, no. 2 (2011).

38. Kamaldeen Ahmed, interview by author, Nima Accra, 12 December 2015.

39. The school is run by his students as he focuses on adult education in morning and evening. Bamba teaches the Arabic language on a daily basis in the morning. He teaches Quran and tajwid every Wednesday after fajr prayer (the dawn prayer), and in the evening both the students and the public gather in his mosque for tafsir. Friday evening has also been scheduled for Islamic jurisprudence and the study of hadith.

40. Roman Loimeier, 'Patterns and Peculiarities of Islamic Reform in Africa'.

41. Yunus Dumbe, 'Islamic Revivalism in Contemporary Ghana'.

42. A mufti is a Muslim scholar who is an expert in legal matters connected with Islam.

43. Literary production is the medium through which Muslim reformers communicate effectively with the masses.

44. Abdul Razak Iddriss, 'Alhaj Umar of Keta Krachie'; John Hunwick, Arabic Literature of Africa: Volume 4. 45. Aminu Bamba, al-Qawl al-Haqq: al-Fasil Bayn al-Haqq wa al-Batil (The Truth that Separates Right from Wrong) (unpublished manuscript, 1997).

46. Aminu Bamba, Complaint to Almighty Allah, Collection of Poems (unpublished manuscript, 2014).

47. Aminu Bamba, You Know Allah? (unpublished manuscript, 1988). 
48. Aminu Bamba, The Accepted Prayer is to Face the Qibla (unpublished manuscript, 2003); Aminu Bamba, The Right Time for Prayer (unpublished manuscript, 1999).

49. Accra is the capital of the Republic of Ghana.

50. Talha Bin Aslam, Abdul Azeem and Syed Javed Arif , 'Design and Implementation of Low Cost Digital Timetable for Prayers' (paper presented at the International Conference on Electrical, Electronics and Computer Engineering (UPCON), Aligarh, India, 2019).

51. Aaron Rock-Singer, 'Prayer and the Islamic Revival: A Timely Challenge' in International fournal of Middle East Studies 48, no. 2 (2016): 293-312.

52. Aminu Bamba, Fath al-Mannan (Accra: Islamic Council for Development and Humanitarian Services, 2002).

53. Bamba however failed to cite the source of the hadith

54. Abdul Mumin Harun and Abdul Wadud Haron, interview by author, 14 August 2015, Suame, Kumasi and 18 August 2015, Aboabo No 2, Kumasi. 